\title{
POTENTIOMETRIC AND THERMODYNAMIC STUDIES OF 5-PHENYL AZORHODANINE DERIVATTVES AND THEIR METAL COMPLEXES
}

\author{
M. F. El-Sherbiny \\ Basic Engineering Science Department, \\ Faculty of Engineering, \\ Minoufiya University, Shebin El-Kom, Egypt
}

\author{
N. E. Salam \\ Mathematical and Physical Science Dept., \\ Faculty of Engineering, \\ Mansoura University, Mansoura, Egypt
}

\begin{abstract}
A series of 5-phenylazo-2-thioxo-4-thiazolidinone derivatives $\left(L_{1}-L_{5}\right)$ have been prepared and characterized by elemental analysis, and IR spectra. Rhodanine and its derivatives are used as an inhibition of mycobacterium tuberculosis and in medicinal preparations. Azo compounds based on rhodanine play a central role as chelating agents for a large number of metal ions, as they form a stable six-membered ring after complexation with the metal ion and can also be used as analytical reagents. Proton-ligand dissociation constants of $\left(\mathrm{L}_{1}-\mathrm{L}_{5}\right)$ and their metal-ligand stability constants of their complexes with $\left(\mathrm{Mn}^{2+}, \mathrm{Co}^{2+}, \mathrm{Ni}^{2+}, \mathrm{Cu}^{2+}, \mathrm{Cd}^{2+}, \mathbf{L a}^{3+}, \mathbf{H f}^{3+}\right.$, and $\left.\mathbf{Z r}^{4+}\right)$ metal ions have been determined potentiometrically in $0.1 \mathrm{M} \mathrm{KCl}$ and $40 \%(\mathrm{v} / \mathrm{v})$ ethanol-water mixture. The influence of substituents on the dissociation and stability constants was examined on the basis of the electron repelling property of the substituent. The order of the stability constants of the formed complexes was found to be $\mathbf{M n}^{2+}<\mathbf{C o}^{2+}<\mathbf{N i}^{2+}<\mathbf{C u}^{2+}<\mathbf{C d}^{2+}<\mathbf{L a}^{3+}<\mathbf{H f}^{3+}<\mathbf{Z r}^{4+}$. The effect of temperature was studied and the corresponding thermodynamic parameters $(\Delta G, \Delta H$ and $\Delta S)$ were derived and discussed. The dissociation process is nonspontaneous, endothermic and entropically unfavourable. The formation of the metal complexes has been found to be spontaneous, endothermic and entropically favourable.

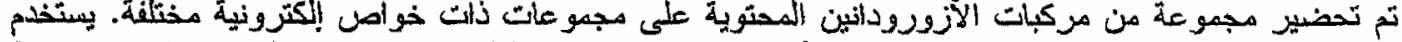

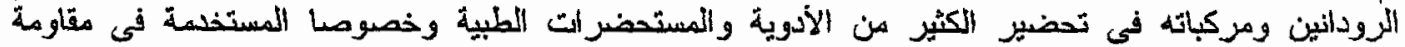

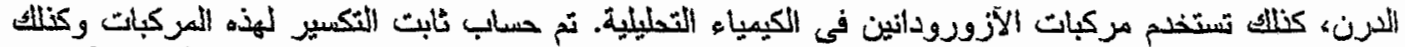

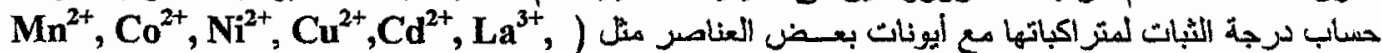

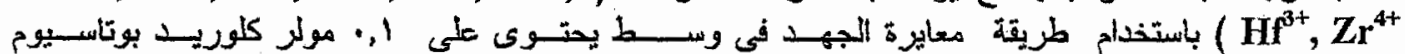

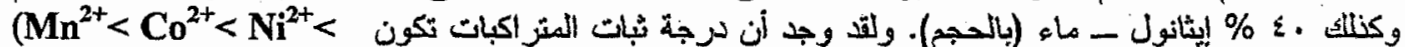

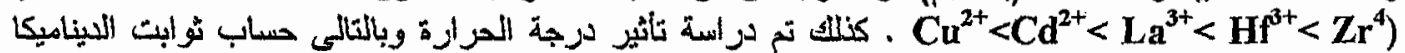

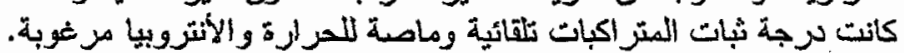

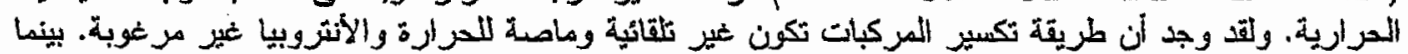

Keywords: 5-Phenylazorhodanines, Potentiometry, Complexation, Thermodynamic.

\section{INTRODUCTION}

Chemistry of rhodanine and its derivatives has attracted special interest due to their inhibition of mycobacterium tuberculosis [1] and as potential medicinal preparations [2]. Azo compounds based on rhodanine play a central role as chelating agents for a large number of metal ions, as they form a stable sixmembered ring after complexation with the metal ion and can also be used as analytical reagents [3]. In continuation to the earlier work [4-8], herein the synthesis of 5-phenylazo-2-thioxo-4-thiazolidinone derivatives are reported. The stability constants of
$\mathrm{Mn}^{2+}, \mathrm{Co}^{2+}, \mathrm{Ni}^{2+}, \mathrm{Cu}^{2+}, \mathrm{Cd}^{2+}, \mathrm{La}^{3+}, \mathrm{Hr}^{3+}$, and $\mathrm{Zr}^{4+}$ complexes with 5-phenylazorhodanine derivatives at different temperatures and substituent effects on the dissociation and stability constants are also investigated. Furthermore, the corresponding thermodynamic functions of dissociation and complexation are evaluated and discussed.

\section{MATERIALS AND METHODS}

5-phenylazo-2-thioxo-4-thiazolidinone derivatives $\left(\mathrm{L}_{1}-\mathrm{L}_{5}\right)$ were prepared. The standard chemical aniline or 4-alkyl-aniline and rhodanine were used as received from Aldrich. The experimental technique 
has been described previously [6-8]. Chemical structure of azorhodanine derivatives is shown in Fig.(1). In a typical preparation, $25 \mathrm{ml}$ of bidistilled water containing 0.01 mole hydrochloric acid were added to 0.01 mole aniline or 4-alkyl-aniline. To the resulting mixture stirred and cooled to $0^{\circ} \mathrm{C}$, a solution of 0.01 mole sodium nitrite in $20 \mathrm{ml}$ of water was added dropwise. The so formed diazonium chloride was consecutively coupled with an alkaline solution of 0.01 mole 2-thioxo-4-thiazolidinone, in $20 \mathrm{ml}$ of pyridine. The coloured precipitate, which formed immediately was filtered, washed several times with water. The crude product was purified by recrystallization from hot ethanol, yield $65 \%$ then dried in vacuum desicator over $\mathrm{P}_{2} \mathrm{O}_{5}$. The ligands were also characterized by elemental analysis (Table 1) and I.R. spectroscopy.

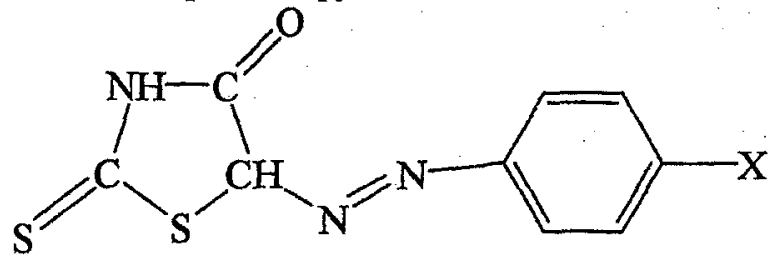

Fig. 1 Derivatives chemical structure; $\mathrm{X}=\mathrm{OCH}_{3}$

$\left(\mathrm{L}_{1}\right), \mathrm{CH}_{3}\left(\mathrm{~L}_{2}\right), \mathrm{H}\left(\mathrm{L}_{3}\right), \mathrm{Cl}\left(\mathrm{L}_{4}\right)$ and $\mathrm{NO}_{2}\left(\mathrm{~L}_{5}\right)$

Metal ion solutions ( $0.0002 \mathrm{M})$ were prepared from Analar metal chloride in bidistilled water and standardized with EDTA [9]. The ligand solution $(0.001 \mathrm{M})$ was prepared by dissolving the accurate mass of the solid in ethanol (Analar). Solutions of $0.01 \mathrm{M} \mathrm{HCl}$ and $1 \mathrm{M} \mathrm{KCl}$ were also prepared in bidistilled water. A carbonate-free sodium hydroxide solution in $40 \%$ (v/v) ethanol-water mixture was used as titrant and standardized against oxalic acid (Analar). The apparatus, general conditions and methods of calculation were the same as in the previous work [6-8]. The following mixtures (i)-(iii) were prepared and titrated potentiometrically at 298 $\mathrm{K}$ against standard $0.02 \mathrm{M} \mathrm{NaOH}$ in $40 \%(\mathrm{v} / \mathrm{v})$ ethanol-water mixture:

i- $5 \mathrm{~mL} 0.01 \mathrm{M} \mathrm{HCl}+5 \mathrm{~mL} 1 \mathrm{M} \mathrm{KCl}+20 \mathrm{~mL}$ ethanol.

ii- $5 \mathrm{~mL} 0.01 \mathrm{M} \mathrm{HCl}+5 \mathrm{~mL} 1 \mathrm{M} \mathrm{KCl}+15 \mathrm{~mL}$ ethanol $+5 \mathrm{~mL} 0.001 \mathrm{M}$ ligand.

iii- $5 \mathrm{~mL} 0.01 \mathrm{M} \mathrm{HCl}+5 \mathrm{~mL} 1 \mathrm{M} \mathrm{KCl}+15 \mathrm{~mL}$ ethanol $+5 \mathrm{~mL} 0.001 \mathrm{M}$ ligand $+5 \mathrm{~mL} 0.0002 \mathrm{M}$ metal salt.

For each mixture, the volume was made up to 50 $\mathrm{mL}$ with bidistilled water before the titration. These titrations were repeated for temperatures of 308 and $318 \mathrm{~K}$. A constant temperature was maintained at \pm $0.05 \mathrm{~K}$ by using an ultrathermostat (Neslab $2 \mathrm{RTE}$ 220). The $\mathrm{pH}$ measurements were carried out using VWR Scientific instruments model $8000 \mathrm{pH}$-meter accurate to \pm 0.01 units. The $\mathrm{pH}$-meter readings in
$40 \%(\mathrm{v} / \mathrm{v})$ ethanol-water mixture are corrected according to the Van Uitert and Hass relation [10].

\section{RESULTS AND DISCUSSION}

\subsection{Proton-ligand stability constants}

The average number of protons associated with the ligands at different $\mathrm{pH}$ values, $\overline{\mathrm{n}}_{\mathrm{A}}$, were calculated from the titration curves of the acid in the absence and presence of a ligand. Thus, the formation curves $\left(\bar{n}_{\mathrm{A}} v s\right.$. $\left.\mathrm{pH}\right)$ for the proton-ligand systems were constructed and found to extend between 0 and 2 in the $\bar{n}_{A}$ scale. Ligands $\left(L_{1}-L_{5}\right)$ have two ionizable protons (the enolized hydrogen ions of the $-\mathrm{SH}$ group in the rhodanine moiety, $\mathrm{pK}_{1}{ }^{\mathrm{H}}$ and in hydrazo from, $\mathrm{pK}_{2}{ }^{\mathrm{H}}$ ) [11]. It can be seen that for the same volume of $\mathrm{NaOH}$ added the ligand titration curves had a lower $\mathrm{pH}$ value than the acid titration curve. The displacement of a ligand titration curve along the volume axis with respect to the acid titration curve is an indication of proton dissociation. The proton-ligand stability constants were calculated using the method of Irving and Rossotti [12]. The -SH group is known to be highly acidic, indicating a weaker bonding between the proton and the sulphur donor. This means that the proton-ligand stability constant of $\mathrm{pK}_{1}{ }^{\mathrm{H}}$ of $\left(\mathrm{L}_{1}-\mathrm{L}_{5}\right)$ should be low due to the dissociation of the -SH group [13].Three types of tautomerism can be suggested for the compounds $L_{1}$. $\mathrm{L}_{5}$ as follows [7].<smiles>C=CN=NC1SC(=S)NC1=O</smiles><smiles>CN=NC1SC(S)=NC1=O</smiles><smiles>C=CN=NC1SC(=S)NC1=O</smiles><smiles>CN=Nc1sc(=S)[nH]c1O</smiles><smiles>C=CC1SC(=S)NC1=O</smiles><smiles>CN/N=C1/SC(=S)NC1=O</smiles>

\subsection{Substituent effect on pK}

An inspection of the results in Table 2 reveals that the $\mathrm{pK}^{\mathrm{H}}$ values of 5-phenyl azorhodanine $\left(\mathrm{L}_{3}\right)$ and its substituted derivatives are influenced by the inductive or mesomeric effect of the substituents. The $\mathrm{p}-\mathrm{OCH}_{3}$ and $\mathrm{p}-\mathrm{CH}_{3}$ derivatives $\left(\mathrm{L}_{1}\right.$ and $\left.\mathrm{L}_{2}\right)$ have a lower acidic character (higher $\mathrm{pK}^{\mathrm{H}}$ values) than the $\mathrm{p}-\mathrm{Cl}$ and $\mathrm{p}-\mathrm{NO}_{2}$ derivatives $\left(\mathrm{L}_{4}\right.$ and $\left.\mathrm{L}_{5}\right)$. This is quite reasonable because the presence of $\mathrm{p}-\mathrm{OCH}_{3}$ and $\mathrm{p}$ $\mathrm{CH}_{3}$ groups (i.e. an electron donating effect) will enhance the electron density by their high positive inductive or mesomeric effect, where by a stronger $\mathrm{O}-\mathrm{H}$ bond is formed. The presence of $\mathrm{p}-\mathrm{Cl}$ and $\mathrm{p}-\mathrm{NO}_{2}$ groups (i.e. an electron withdrawing effect) will lead to the opposite effect. The results are also in accordance with Hammett's para substituent constant 
values $\sigma^{x}$ [7,14]. Straight lines are obtained on plotting $\mathrm{pK}^{\mathrm{H}}$ values at different temperatures versus $\sigma^{x}$ (Figs. 2, 3). The para substituents have a direct influence on the $\mathrm{pK}^{\mathrm{H}}$ values of the investigated compounds, revealing the co-planarity of the molecule and thus affording a maximum resonance via delocalization of its $\pi$-system.

\subsection{Metal-ligand stability constants}

The formation curves for the metal complexes were obtained by plotting the average number of ligands attached per metal ions $(\bar{n})$ versus the free ligand exponent ( $\mathrm{pL}$ ), according to Irving and Rossotti [15]. These curves were analyzed and the successive stability constants were determined using different computational methods $[16,17]$ which agree within $1 \%$ error. Accordingly, the average values are represented in Table 3 . The following general remarks can be pointed out:

(i) The maximum value of $\bar{n}$ was $\approx 2$ indicating the formation of 1:1 and 1:2 (metal:ligand) complexes only.

(ii) The metal ion solution used in the present study was very dilute $\left(2 \times 10^{-5} \mathrm{M}\right)$, hence there was no possibility of formation of polynuclear complexes [18].

(iii) The metal titration curves were displaced to the right-hand side of the ligand titration curves along the volume axis, indicating proton release upon complex formation of the metal ion with the ligand. The large decrease in $\mathrm{pH}$ for the metal titration curves relative to ligand titration curves point to the formation of strong metal complexes [19].

(iv) In most cases, the colour of the solution after complex formation was observed to be different from the colour of the ligand at the same $\mathrm{pH}$.

(v) For the same ligand at constant temperature, the stability of the chelates increases in the order $\mathrm{Mn}^{2+}<$ $\mathrm{Co}^{2+}<\mathrm{Ni}^{2+}<\mathrm{Cu}^{2+}<\mathrm{Cd}^{2+}<\mathrm{La}^{3+}<\mathrm{Hf}^{3+}<\mathrm{Zr}^{4+}[20,21]$. This order largely reflects the changes in the heat of complex formation across the series from a combination of the influence of both the polarizing ability of the metal ion [22] and the crystal-field stabilization energies [23].

3.4 Effect of the substituent $X$ on the stability of the complexes

An inspection of the results in Table 3 reveals that the stability constant values of the complexes of $\mathrm{L}_{3}$ and its substituted derivatives are influenced by the inductive or mesomeric effect of the substituents. This behaviour correlates with the effect of substitution on the phenyl ring as follows:

(i) The high stability of $\mathrm{L}_{1}$ and $\mathrm{L}_{2}$ complexes can be attributed to the presence of the $-\mathrm{OCH}_{3}$ and $-\mathrm{CH}_{3}$ groups in the p-position relative to the azo group, respectively. This is quite reasonable because the presence of $\mathrm{p}-\mathrm{OCH}_{3}$ and $\mathrm{p}-\mathrm{CH}_{3}$ groups (i.e. an electron donating effect) will enhance the electron density by their high positive indicative or mesomeric effect, whereby stronger chelation was formed and therefore the stability of the complexes.

(ii) The low stability of $\mathrm{L}_{5}$ and $\mathrm{L}_{4}$ complexes can be attributed to the presence of the $-\mathrm{NO}_{2}$ and $-\mathrm{Cl}$ groups in the p-position relative to the azo group, respectively. This is caused by the negative indicative effect of the $-\mathrm{NO}_{2}$ and $-\mathrm{Cl}$ groups which decreases its ability for chelation and therefore the stability of the complexes.

(iii) For the ligands with the same metal ion at constant temperature, the stability of the chelates decreases in the order $L_{1}>L_{2}>L_{3}>L_{4}>L_{5}[7,24]$.

3.5 Effect of temperature

The dissociation constant $\left(\mathrm{pK}^{\mathrm{H}}\right)$ for 5-phenyl azorhodanine $\left(\mathrm{L}_{3}\right)$ and its derivatives, as well as the stability constants of their complexes with $\mathrm{Mn}^{2+}$, $\mathrm{Co}^{2+}, \mathrm{Ni}^{2+}, \mathrm{Cu}^{2+}, \mathrm{Cd}^{2+}, \mathrm{La}^{3+}, \mathrm{Hf}^{3+}$ and $\mathrm{Zr}^{4+}$ have been evaluated at 298,308 and $318 \mathrm{~K}$, and are given in Table 2 and 4 . The enthalpy change $(\Delta H)$ for the dissociation or complexation process were calculated from the slope of the plot $\left(\mathrm{pK}^{\mathrm{H}}\right.$ or $\left.\log K v s .{ }^{1} / \mathrm{T}\right)$ (Figs. 4-7) using the graphical representation of van't Hoff equation:

$$
\begin{aligned}
& -2.303 R T \log =\Delta H-T \Delta S \\
& \text { or } \\
& \log K=(-\Delta H / 2.303 R)(1 / T)+(\Delta S / 2.303 R)
\end{aligned}
$$$$
\text { or }
$$

From the free energy change $(\Delta G)$ and $(\Delta H)$ values one can deduce the entropy changes $(\Delta S)$ using the well known relationships (3) and (4) :

$$
\Delta G=-2.303 R T \log K
$$$$
\Delta S=(\Delta H-\Delta G) / T
$$

where the gas constant $R=8.314 \mathrm{~J} \mathrm{~K}^{-1} \mathrm{~mol}^{-1}, K$ is the dissociation constant for the ligand or the stability constant of the complex, and $T$ absolute temperature.

All thermodynamic parameters of the dissociation process of $\mathrm{L}_{3}$ and its derivatives are recorded in Table 2. From these results the following conclusions can be made:

(a) The $\mathrm{pK}^{\mathrm{H}}$ values decrease with increasing temperature, i.e., the acidity of the ligands increases, independent of the nature of the substituent [7].

(b) A positive value of $\Delta H$ indicates that the process is endothermic.

(c) A large positive value of $\Delta G$ indicates that the dissociation process is not spontaneous [25].

(d) The dissociation processes for $\mathrm{L}_{3}$ and its derivatives have negative values of $\Delta S$ due to increase order as a result of the solvation processes.

All the thermodynamic parameters of the stepwise stability constants of complexes are recorded in Table 4. It is known that the metal ions exist in solution as octahedrally hydrated species [17] and the obtained values of $\Delta H$ and $\Delta S$ can then be considered as the sum of two contributions: (a) release of $\mathrm{H}_{2} \mathrm{O}$ molecules, and (b) metal-ligand bond formation. Examination of these values shows that: 
(i) The stepwise stability constants $\left(\log K_{l}\right.$ and $\log$ $K_{2}$ ) for ligand complexes increases with increasing temperature, i.e., its stability constants increase with increasing the temperature.

(ii) The negative value of $\Delta G$ for the complexation process suggests the spontaneous nature of such process [24].

(iii) The $\Delta H$ values are positive, meaning that these processes are endothermic and favourable at higher temperature.

(iv) The $\Delta S$ values for the ligand complexes are positive, confirming that the complex formation is entropically favourable [5]

\section{CONCLUSIONS}

The following conclusions can be withdrawn from this research:

1. The order of the stability constants of the formed complexes were found to be $\mathrm{Mn}^{2+}<\mathrm{Co}^{2+}<\mathrm{Ni}^{2+}<$ $\mathrm{Cu}^{2+}<\mathrm{Cd}^{2+}<\mathrm{La}^{3+}<\mathrm{Hr}^{3+}<\mathrm{Zr}^{4+}$.

2 . The dissociation process of 5 -phenyl azorhodanine and its derivatives is nonspontaneous, endothermic and entropically unfavourable.

3. The formation of the metal complexes has been found to be spontaneous, endothermic and entropically favourable.

\section{REFERENCES}

[1] S. Tadashi and O. Masaki, J. Pharm. Soc. (Japan), 75,1535 (1955).

[2] F.C. Brown, C.K. Bradsher, B.F. Moser and S. Forrester, J. Org. Chem. 24, 1056 (1959).

[3] A.C. Fabretti and G. Peyronel, Transition Met. Chem. 2, 224 (1977).

[4] M.F. El-Sherbiny,A.A. Al-Sarawy and A.A. ElBindary., Boll. Chim. Farmac-Anno. 141, 274 (2002).

[5] A. A. Al-Sarawy, A. A. Al-Bindary, A. Z. ElSonbati and T. Y. Omar, Chem. Pap., 59,261 (2005).

[6] A. Z. El-Sonbati, A. A. El-Bindary and R. M. Ahmed, J. Sol. Chem. 32, 617 (2003).

[7] A. A. El-Bindary, A.Z . El-Sonbati, E.H. ElMosalamy and R. M. Ahmed, Chem. Pap. 57, 255 (2003).
[8] A. A. Al-Sarawy, Chem. Pap. 58, 109 (2004).

[9] G. H. Jeffery, J. Bassett, J. Mendham and R. C. Deney, "Vogel's Textbook of Quantitative Chemical Analysis", $5^{\text {th }}$ Edn., Longman, London, (1989).

[10] L.G. Van Uitert and C.G. Hass, J. Am. Chem. Soc. 75, 451 (1953).

[11] B. A. El-Shetary, S. L. Stefan, F. I. Zidan and S. B. El-Maraghy, Monatsh.Chem. 118, 1101(1987).

[12] H. Irving and H.S. Rossotti, J. Chem. Soc. 2904 (1954).

[13] V.D. Athawale and S.S. Nerkar, Monatsh. Chem. 131, 267 (2000).

[14] J. Hine, "Structural Effects of Equilibria in Inorganic Chemistry", Wiley, New York, p. 667, (1975).

[15] H. Irving and H. S. Rossotti, J. Chem. Soc. 3397 (1953).

[16] F. I. C. Rossotti and H. S. Rossotti, Acta Chem. Scand. 9, 1166 (1955).

[17] M. T. Beck and I. Nagybal, "Chemistry of Complex Equilibrium", Wiley, New York (1990).

[18] P. Sanyal and G. P. Sengupta, J. Ind. Chem. Soc. 67, 342 (1990).

[19] V. D. Athawale and V. Lele, J. Chem. Eng. Data. 41, 1015 (1996).

[20] G. A. Ibañez and G. M. Escandar, Polyhedron. 17,4433 (1998).

[21] F. R. Harlly, R. M. Burgess and R. M. Alcock, "Solution Equilibria", Ellis Harwood, Chichester, p. 257 (1980).

[22] C. S. G. Phillips and R. J. P. Williams, "Inorganic Chemistry", Vol. 2. P. 268. Oxford University Press, New York, (1966).

[23] A. T. Mubarak, J. Sol. Chem. 33, 149 (2004).

[24] A. Bebot-Bringaud, C. Dange, N. Fauconnier and C. Gerard, J. Inorg. Biochem. 75, 71 (1999).

[25] W. U. Malik, G. D. Tuli and R. D. Madan, "Selected Topics in Inorganic Chemistry", $3^{\text {rd }}$ Edn. S. Chand \& Company LTD, New Delhi. (1984). 


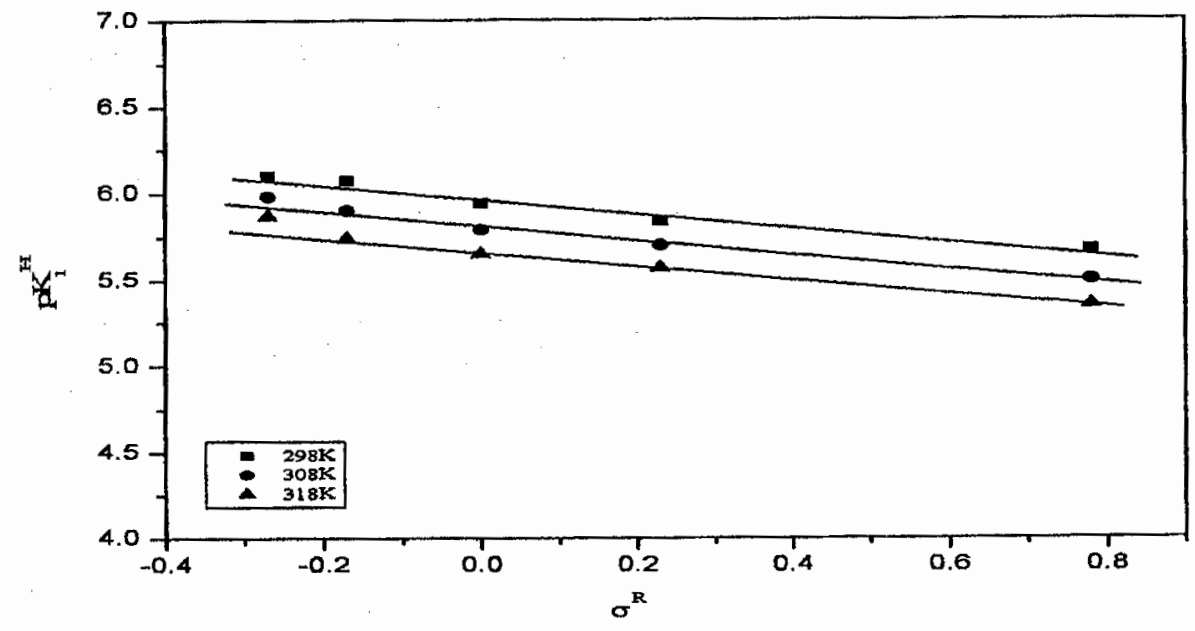

Fig. 2 Correlation of $\mathrm{pK}_{1}{ }^{\mathrm{H}}$ with Hammett's constant $\sigma^{\mathrm{R}}$ at 298,308 and $318 \mathrm{~K}$

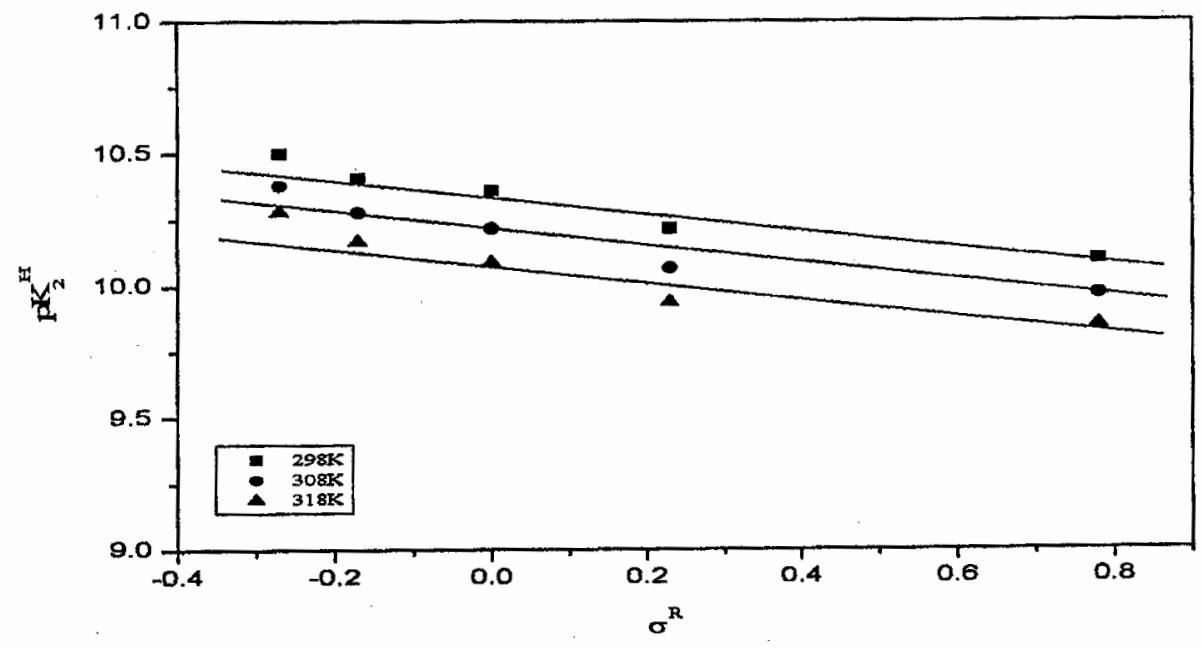

Fig. 3 Correlation of $\mathrm{pK}_{2}{ }^{\mathrm{H}}$ with Hammett's constant $\sigma^{\mathrm{R}}$ at 298,308 and $318 \mathrm{~K}$

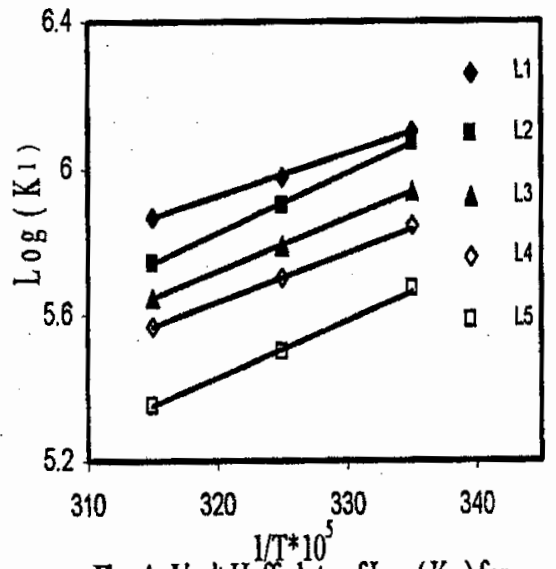

Fig. 4 : Van't Hoff plots of $\log \left(\mathrm{K}_{1}\right)$ for different derivatives against $1 / T$.

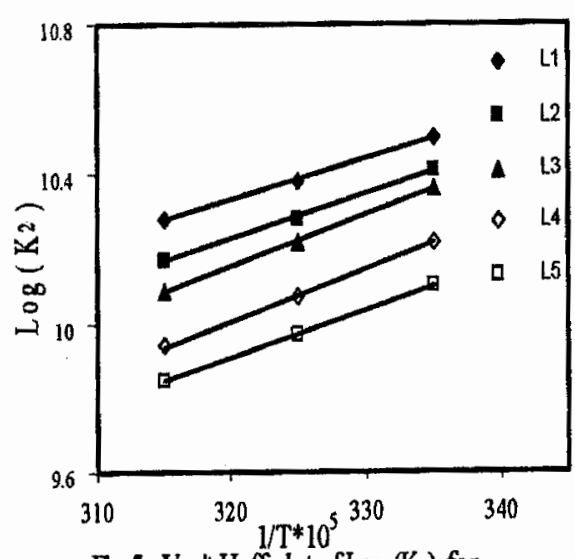

Fig. 5 : Van't Hoff plot of $\log \left(K_{2}\right)$ for different derivatives against $1 / T$. 


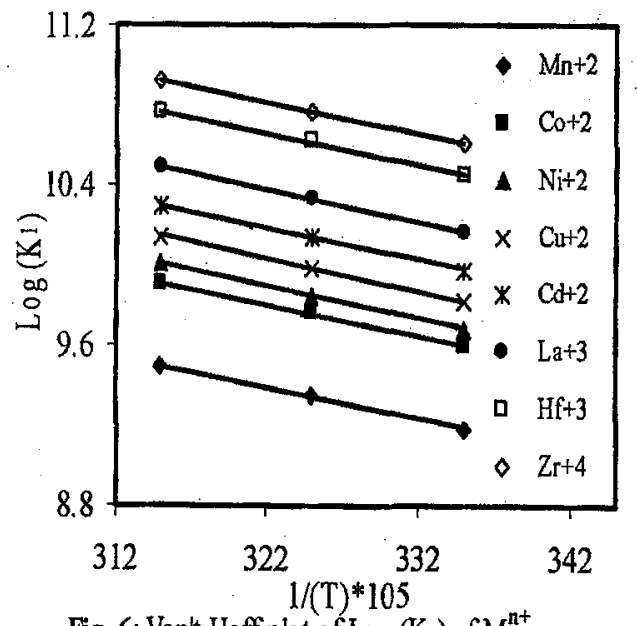

Fig. 6: Van't Hoff plot of $\log \left(K_{1}\right)$ of $\mathrm{M}^{\mathrm{n}+}$ complexes with $\mathrm{Ll}_{1}$ against $1 / \mathrm{T}$.

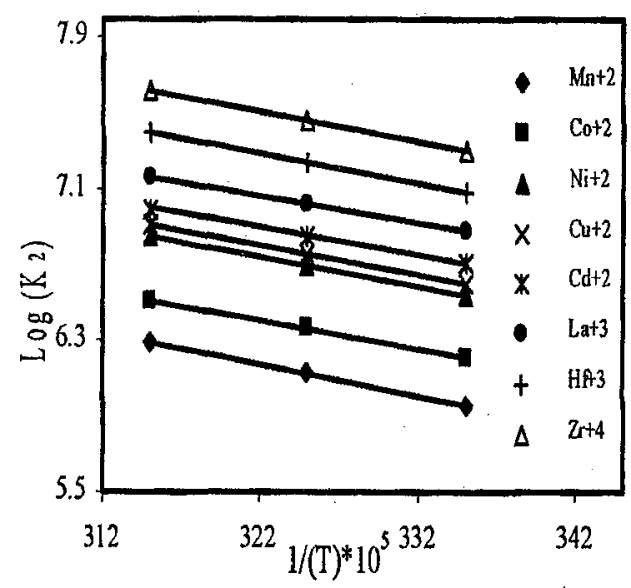

Fig. 7 : Van't Hoff plot of $\log \left(\mathrm{K}_{2}\right)$ of $\mathrm{M}^{\mathrm{nt}}$ complexes of $\mathrm{L}$ against $1 / \mathrm{T}$.

Table 1 Analytical data of 5-phenylazorhodanine derivatives $\left(\mathrm{L}_{1}-\mathrm{L}_{5}\right)$

\begin{tabular}{|c|c|c|c|c|c|c|c|}
\hline \multirow[t]{2}{*}{ Compound } & \multirow{2}{*}{$\begin{array}{c}\text { Empirical } \\
\text { formula }\end{array}$} & \multirow{2}{*}{$\begin{array}{c}\text { Formula Weight } \\
(\mathrm{g} / \mathrm{mol})\end{array}$} & \multirow[t]{2}{*}{ Colour } & \multirow[t]{2}{*}{ m.p. ${ }^{\circ} \mathrm{C}$} & \multicolumn{3}{|c|}{ Calc. (Exp.)\% } \\
\hline & & & & & $\overline{\mathrm{C}}$ & $\overrightarrow{\mathrm{H}}$ & $\bar{N}$ \\
\hline $\mathrm{L}_{1}$ & $\mathrm{C}_{10} \mathrm{H}_{9} \mathrm{~N}_{3} \mathrm{O}_{2} \mathrm{~S}_{2}$ & 267 & Red & 198 & 44.94 & 3.37 & 15.73 \\
\hline & & & & & (44.82) & $(3.25)$ & $(15.85)$ \\
\hline $\mathrm{L}_{2}$ & $\mathrm{C}_{10} \mathrm{H}_{9} \mathrm{~N}_{3} \mathrm{OS}_{2}$ & 251 & Orange & 203 & 47.81 & 3.58 & 16.73 \\
\hline & & & & & $(47.88)$ & $(3.76)$ & (16.61) \\
\hline $\mathrm{L}_{3}$ & $\overline{\mathrm{C}_{9} \mathrm{H}_{7} \mathrm{~N}_{3} \mathrm{OS} \mathrm{S}_{2}}$ & 237 & Red & 139 & 45.56 & 2.95 & 17.72 \\
\hline & & & & & $(45.68)$ & $(2.80)$ & $(17.85)$ \\
\hline $\mathrm{L}_{4}$ & $\mathrm{C}_{9} \mathrm{H}_{6} \mathrm{~N}_{3} \mathrm{OS} \mathrm{S}_{2} \mathrm{Cl}$ & 271 & Yellow & 239 & 39.85 & 2.21 & 15.49 \\
\hline & & & & & $(39.65)$ & $(2.35)$ & $(15.58)$ \\
\hline $\mathrm{L}_{5}$ & $\mathrm{C}_{9} \mathrm{H}_{6} \mathrm{~N}_{4} \mathrm{O}_{3} \mathrm{~S}_{2}$ & 282 & Brown & 245 & 38.29 & 2.13 & 19.85 \\
\hline & & & & & $(38.42)$ & $(2.25)$ & $(19.98)$ \\
\hline
\end{tabular}

Table 2 Thermodynamic Functions for the Dissociation of $\mathrm{L}_{1}-\mathrm{L}_{5}$ in $40 \%(\mathrm{v} / \mathrm{v})$ Ethanol-

Water Mixture and $0.1 \mathrm{M} \mathrm{KCl}$ at Different Temperatures

\begin{tabular}{|c|c|c|c|c|c|c|c|c|c|}
\hline \multirow[t]{2}{*}{ Compound } & \multirow{2}{*}{$\begin{array}{l}\text { Temp. } \\
\text { (K) }\end{array}$} & \multicolumn{2}{|c|}{$\begin{array}{l}\text { Dissociation } \\
\text { constant }\end{array}$} & \multicolumn{2}{|c|}{$\begin{array}{l}\text { Free energy change } \\
\left(\mathrm{kJ} \cdot \mathrm{mol}^{-1}\right)\end{array}$} & \multicolumn{2}{|c|}{$\begin{array}{l}\text { Enthalpy change } \\
\left(\mathrm{kJ} . \mathrm{mol}^{-1}\right)\end{array}$} & \multicolumn{2}{|c|}{$\begin{array}{l}\text { Entropy change } \\
\left(\mathrm{J} \cdot \mathrm{mol}^{-1} \cdot \mathrm{K}^{-1}\right)\end{array}$} \\
\hline & & \multicolumn{2}{|l|}{$\mathrm{pK}_{1}{ }^{\mathrm{H}}$} & $\Delta \mathrm{G}_{1}$ & $\Delta \mathrm{G}_{2}$ & $\Delta \mathrm{H}_{1}$ & $\Delta \mathrm{H}_{2}$ & $-\Delta S_{1}$ & $-\Delta S_{2}$ \\
\hline $\mathrm{L}_{1}$ & 298 & 6.1 & 10.50 & 34.80 & 59.91 & \multirow{3}{*}{20.87} & \multirow{3}{*}{19.96} & 46.74 & 134.10 \\
\hline & 308 & 5.98 & 10.38 & 35.26 & 61.21 & & & 46.72 & 133.93 \\
\hline & 318 & 5.87 & 10.28 & 35.74 & 62.59 & & & 46.76 & 134.1 \\
\hline \multirow[t]{3}{*}{$\mathrm{L}_{2}$} & 298 & 6.07 & 10.41 & 34.63 & 59.39 & \multirow{3}{*}{29.94} & \multirow{3}{*}{21.77} & 15.75 & 126.21 \\
\hline & 308 & 5.90 & 10.28 & 34.79 & 60.62 & & & 15.74 & 126.13 \\
\hline & 318 & 5.74 & 10.17 & 34.94 & 61.92 & & & 15.72 & 126.25 \\
\hline \multirow[t]{3}{*}{$\mathrm{L}_{3}$} & 298 & 5.94 & 10.36 & 33.89 & 59.11 & \multirow{3}{*}{26.31} & \multirow{3}{*}{24.50} & 25.43 & 116.14 \\
\hline & 308 & 5.79 & 10.22 & 34.14 & 60.27 & & & 25.42 & 116.13 \\
\hline & 318 & 5.65 & 10.09 & 34.40 & 61.43 & & & 25.44 & 116.13 \\
\hline \multirow[t]{3}{*}{$\overline{\mathrm{L}_{4}}$} & 298 & 5.84 & 10.22 & 33.32 & 58.31 & \multirow{3}{*}{24.50} & \multirow{3}{*}{25.40} & 29.59 & 110.43 \\
\hline & 308 & 5.70 & 10.07 & 33.61 & 59.38 & & & 29.57 & 110.32 \\
\hline & 318 & 5.57 & 9.94 & 33.91 & 60.52 & & & 29.59 & 110.44 \\
\hline \multirow[t]{3}{*}{$\mathrm{L}_{5}$} & 298 & 5.67 & 10.10 & 32.35 & 57.62 & \multirow{3}{*}{29.94} & \multirow{3}{*}{22.68} & 8.08 & 117.24 \\
\hline & 308 & 5.50 & 9.97 & 32.43 & 58.79 & & & 8.08 & 117.24 \\
\hline & 318 & 5.35 & 9.85 & 32.51 & 59.97 & & & 8.08 & 117.26 \\
\hline
\end{tabular}


Table 3 Stepwise Stability Constants for $\mathrm{ML}_{1}$ and $\mathrm{ML}_{2}$ Complexes of $\left(\mathrm{L}_{1}-\mathrm{L}_{5}\right)$ in $40 \%$ (v/v)

Ethanol-Water Mixtures and $0.1 \mathrm{M} \mathrm{KCl}$ at Different Temperatures

\begin{tabular}{|c|c|c|c|c|c|c|c|}
\hline \multirow[b]{2}{*}{ Compound } & \multirow[b]{2}{*}{$\mathbf{M}^{\mathrm{n}+}$} & \multicolumn{2}{|c|}{$298 \mathrm{~K}$} & \multicolumn{2}{|c|}{$308 \mathrm{~K}$} & \multicolumn{2}{|c|}{$318 \mathrm{~K}$} \\
\hline & & $\log K_{I}$ & $\log \mathrm{K}_{2}$ & $\log \mathrm{K}_{\mathrm{I}}$ & $\log K_{2}$ & $\log K_{1}$ & $\log \mathrm{K}_{2}$ \\
\hline \multirow[t]{8}{*}{$\mathrm{L}_{1}$} & $\mathrm{Mn}^{2+}$ & 9.18 & 5.96 & 9.35 & 6.13 & 9.49 & 6.28 \\
\hline & $\mathrm{Co}^{2+}$ & 9.59 & 6.21 & 9.76 & 6.37 & 9.91 & 6.51 \\
\hline & $\mathrm{Ni}^{2+}$ & 9.68 & 6.53 & 9.85 & 6.70 & 10.01 & 6.85 \\
\hline & $\mathrm{Cu}^{2+}$ & 9.82 & 6.60 & 9.99 & 6.76 & 10.15 & 6.91 \\
\hline & $\mathrm{Cd}^{2+}$ & 9.98 & 6.71 & 10.15 & 6.86 & 10.30 & 7.00 \\
\hline & $\mathrm{La}^{3+}$ & 10.17 & 6.88 & 10.34 & 7.03 & 10.50 & 7.17 \\
\hline & $\mathrm{Hf}^{3+}$ & 10.46 & 7.09 & 10.62 & 7.25 & 10.77 & 7.40 \\
\hline & $\mathrm{Zr}^{4+}$ & 10.61 & 7.31 & 10.77 & 7.47 & 10.92 & 7.62 \\
\hline \multirow[t]{8}{*}{$\mathrm{L}_{2}$} & $\mathrm{Mn}^{2+}$ & 9.04 & 5.81 & 9.19 & 5.96 & 9.33 & 6.10 \\
\hline & $\mathrm{Co}^{2+}$ & 9.43 & 6.02 & 9.60 & 6.19 & 9.75 & 6.35 \\
\hline & $\mathrm{Ni}^{2+}$ & 9.57 & 6.33 & 9.74 & 6.50 & 9.90 & 6.66 \\
\hline & $\mathrm{Cu}^{2+}$ & 9.70 & 6.41 & 9.86 & 6.58 & 10.01 & 6.73 \\
\hline & $\mathrm{Cd}^{2+}$ & 9.88 & 6.58 & 10.05 & 6.75 & 10.21 & 6.91 \\
\hline & $\mathrm{La}^{3+}$ & 9.97 & 6.69 & 10.14 & 6.86 & 10.30 & 7.01 \\
\hline & $\mathrm{Hf}^{3+}$ & 10.27 & 6.92 & 10.43 & 7.08 & 10.58 & 7.23 \\
\hline & $\mathrm{Zr}^{4+}$ & 10.42 & 7.11 & 10.59 & 7.26 & 10.75 & 7.40 \\
\hline \multirow[t]{8}{*}{$\overline{\mathrm{L}_{3}}$} & $\mathrm{Mn}^{2+}$ & 8.92 & 5.68 & 9.09 & 5.84 & 9.25 & 5.99 \\
\hline & $\mathrm{Co}^{2+}$ & 9.23 & 5.93 & 9.39 & 6.08 & 9.55 & 6.22 \\
\hline & $\mathrm{Ni}^{2+}$ & 9.35 & 6.12 & 9.52 & 6.32 & 9.68 & 6.51 \\
\hline & $\mathrm{Cu}^{2+}$ & 9.49 & 6.27 & 9.66 & 6.44 & 9.82 & 6.60 \\
\hline & $\mathrm{Cd}^{2+}$ & 9.72 & 6.38 & 9.88 & 6.55 & 10.03 & 6.72 \\
\hline & $\mathrm{La}^{3+}$ & 9.86 & 6.58 & 10.02 & 6.74 & 10.18 & 6.89 \\
\hline & $\mathrm{Hf}^{3+}$ & 9.98 & 6.82 & 10.15 & 6.97 & 10.31 & 7.12 \\
\hline & $\mathrm{Zr}^{4+}$ & 10.24 & 7.00 & 10.39 & 7.16 & 10.52 & 7.32 \\
\hline \multirow{8}{*}{$\overline{\mathrm{L}_{4}}$} & $\mathrm{Mn}^{2+}$ & 8.77 & 5.57 & 8.94 & 5.72 & 9.10 & 5.86 \\
\hline & $\mathrm{Co}^{2+}$ & 9.07 & 5.70 & 9.23 & 5.86 & 9.38 & 6.00 \\
\hline & $\mathrm{Ni}^{2+}$ & 9.23 & 6,10 & 9.38 & 6.25 & 9.52 & 6.39 \\
\hline & $\mathrm{Cu}^{2+}$ & 9.39 & 6.23 & 9.55 & 6.38 & 9.69 & 6.51 \\
\hline & $\mathrm{Cd}^{2+}$ & 9.58 & 6.35 & 9.74 & 6.51 & 9.88 & 6.65 \\
\hline & $\mathrm{La}^{3+}$ & 9.68 & 6.40 & 9.85 & 6.56 & 10.00 & 6.71 \\
\hline & $\mathrm{Hf}^{3+}$ & 9.79 & 6.65 & 9.95 & 6.80 & 10.10 & 6.94 \\
\hline & $\mathrm{Zr}^{4+}$ & 9.98 & 6.78 & 10.14 & 6.94 & 10.28 & 7.10 \\
\hline \multirow[t]{8}{*}{$\mathrm{L}_{5}$} & $\mathrm{Mn}^{2+}$ & 8.69 & 5.37 & 8.85 & 5.54 & 9.00 & 5.70 \\
\hline & $\mathrm{Co}^{2+}$ & 8.90 & 5.60 & 9.07 & 5.76 & 9.22 & 5.90 \\
\hline & $\mathrm{Ni}^{2+}$ & 9.07 & 5.98 & 9.24 & 6.13 & 9.40 & 6.26 \\
\hline & $\mathrm{Cu}^{2+}$ & 9.28 & 6.08 & 9.44 & 6.24 & 9.58 & 6.39 \\
\hline & $\mathrm{Cd}^{2+}$ & 9.37 & 6.18 & 9.54 & 6.34 & 9.70 & 6.49 \\
\hline & $\mathrm{La}^{3+}$ & 9.56 & 6.29 & 9.72 & 6.46 & 9.86 & 6.62 \\
\hline & $\mathrm{Hf}^{3+}$ & 9.66 & 6.52 & 9.83 & 6.66 & 9.98 & 6.80 \\
\hline & $\mathrm{Zr}^{4+}$ & 9.83 & 6.58 & 9.98 & 6.75 & 10.12 & 6.91 \\
\hline
\end{tabular}


Table 4 Thermodynamic Functions for $\mathrm{ML}_{1}$ and $\mathrm{ML}_{2}$ Complexes of $\left(\mathrm{L}_{1}-\mathrm{L}_{5}\right)$ in $40 \%(\mathrm{v} / \mathrm{v})$

Ethanol-Water Mixture and $0.1 \mathrm{M} \mathrm{KCl}$ at $298 \mathrm{~K}$

\begin{tabular}{|c|c|c|c|c|c|c|c|}
\hline \multirow[t]{2}{*}{ Compound } & \multirow[t]{2}{*}{$\mathrm{M}^{\mathrm{n}+}$} & \multicolumn{2}{|c|}{$\begin{array}{c}\text { Gibbs energy change } \\
\left(\mathrm{kJ} \cdot \mathrm{mol}^{-1}\right)\end{array}$} & \multicolumn{2}{|c|}{$\begin{array}{l}\text { Enthalpy change } \\
\left(\mathrm{kJ} \cdot \mathrm{mol}^{-1}\right)\end{array}$} & \multicolumn{2}{|c|}{$\begin{array}{l}\text { Entropy change } \\
\left(\mathrm{J} \cdot \mathrm{mol}^{-1} \cdot \mathrm{K}^{-1}\right)\end{array}$} \\
\hline & & $-\Delta G_{l}$ & $-\Delta G_{2}$ & $\Delta H_{1}$ & $\Delta H_{2}$ & $\Delta S_{I}$ & $\Delta S_{2}$ \\
\hline \multirow[t]{8}{*}{$\mathrm{L}_{1}$} & $\mathrm{Mn}^{2+}$ & 52.37 & 34.01 & 28.13 & 29.03 & 270.13 & 211.54 \\
\hline & $\mathrm{Co}^{2+}$ & 54.71 & 35.43 & 29.03 & 27.22 & 281.01 & 210.23 \\
\hline & $\mathrm{Ni}^{2+}$ & 55.23 & 37.25 & 29.94 & 29.03 & 285.80 & 222.41 \\
\hline & $\mathrm{Cu}^{2+}$ & 56.03 & 37.65 & 29.94 & 28.13 & 288.48 & 220.73 \\
\hline & $\mathrm{Cd}^{2+}$ & 56.94 & 38.28 & 29.03 & 26.31 & 288.48 & 216.74 \\
\hline & $\mathrm{La}^{3+}$ & 58.02 & 39.25 & 29.94 & 26.31 & 295.16 & 220.00 \\
\hline & $\mathrm{Hf}^{3+}$ & 59.68 & 40.45 & 28.13 & 28.13 & 294.66 & 230.13 \\
\hline & $\mathrm{Zr}^{4+}$ & 60.53 & 41.70 & 28.13 & 28.13 & 297.51 & 234.39 \\
\hline \multirow[t]{8}{*}{$\overline{L_{2}}$} & $\mathrm{Mn}^{2+}$ & 51.58 & 33.15 & 26.31 & 26.31 & 261.37 & 199.53 \\
\hline & $\mathrm{Co}^{2+}$ & 53.80 & 34.34 & 29.03 & 29.94 & 277.95 & 215.70 \\
\hline & $\mathrm{Ni}^{2+}$ & 54.60 & 36.11 & 29.94 & 29.94 & 283.69 & 221.64 \\
\hline & $\mathrm{Cu}^{2+}$ & 55.34 & 36.57 & 28.13 & 29.03 & 280.10 & 220.13 \\
\hline & $\mathrm{Cd}^{2+}$ & 56.37 & 37.54 & 29.94 & 29.94 & 289.63 & 226.44 \\
\hline & $\mathrm{La}^{3+}$ & 56.88 & 38.17 & 29.94 & 29.03 & 291.34 & 225.50 \\
\hline & $\mathrm{Hf}^{3+}$ & 58.59 & 39.48 & 28.13 & 28.13 & 291.01 & 226.87 \\
\hline & $\mathrm{Zr}^{4+}$ & 59.45 & 40.56 & 29.94 & 26.31 & 299.96 & 224.39 \\
\hline \multirow[t]{8}{*}{$\mathrm{L}_{3}$} & $\mathrm{Mn}^{2+}$ & 50.89 & 32.40 & 29.94 & 28.13 & 271.24 & 203.12 \\
\hline & $\mathrm{Co}^{2+}$ & 52.66 & 33.83 & 29.03 & 36.31 & 274.12 & 201.81 \\
\hline & $\mathrm{Ni}^{2+}$ & 53.34 & 34.91 & 29.94 & 35.39 & 279.46 & 235.90 \\
\hline & $\mathrm{Cu}^{2+}$ & 54.14 & 35.77 & 29.94 & 29.94 & 282.14 & 220.50 \\
\hline & $\mathrm{Cd}^{2+}$ & 55.46 & 36.40 & 28.13 & 30.85 & 280.50 & 225.67 \\
\hline & $\mathrm{La}^{3+}$ & 56.43 & 37.54 & 29.03 & 28.31 & 286.77 & 220.36 \\
\hline & $\mathrm{Hf}^{3+}$ & 56.94 & 38.91 & 29.94 & 27.22 & 291.54 & 221.91 \\
\hline & $\mathrm{Zr}^{4+}$ & 58.42 & 39.94 & 25.40 & 29.03 & 281.27 & 231.44 \\
\hline \multirow[t]{8}{*}{$\mathrm{L}_{4}$} & $\mathrm{Mn}^{2+}$ & 50.03 & 31.78 & 29.94 & 26.31 & 268.35 & 194.93 \\
\hline & $\mathrm{Co}^{2+}$ & 51.75 & 32.52 & 28.13 & 26.22 & 268.05 & 200.46 \\
\hline & $\mathrm{Ni}^{2+}$ & 52.66 & 34.80 & 26.31 & 26.31 & 265.00 & 205.06 \\
\hline & $\mathrm{Cu}^{2+}$ & 53.57 & 35.54 & 27.22 & 25.40 & 271.10 & 204.49 \\
\hline & $\mathrm{Cd}^{2+}$ & 54.66 & 36.23 & 27.22 & 27.22 & 274.76 & 212.91 \\
\hline & $\mathrm{La}^{3+}$ & 55.23 & 36.51 & 29.03 & 28.13 & 282.75 & 216.91 \\
\hline & $\mathrm{Hf}^{3+}$ & 55.85 & 36.51 & 28.13 & 26.31 & 281.81 & 210.80 \\
\hline & $\mathrm{Zr}^{4+}$ & 56.94 & 38.68 & 27.22 & 29.03 & 282.41 & 227.21 \\
\hline \multirow[t]{8}{*}{$\mathrm{L}_{5}$} & $\mathrm{Mn}^{2+}$ & 49.58 & 30.64 & 28.13 & 29.94 & 260.77 & 203.28 \\
\hline & $\mathrm{Co}^{2+}$ & 50.78 & 31.95 & 29.03 & 27.22 & 267.81 & 198.55 \\
\hline & $\mathrm{Ni}^{2+}$ & 51.75 & 34.12 & 29.94 & 25.40 & 274.12 & 199.73 \\
\hline & $\mathrm{Cu}^{2+}$ & 52.94 & 34.69 & 27.22 & 28.13 & 268.99 & 210.80 \\
\hline & $\mathrm{Cd}^{2+}$ & 53.46 & 35.26 & 29.94 & 28.13 & 279.86 & 212.71 \\
\hline & $\mathrm{La}^{3+}$ & 54.54 & 35.88 & 27.22 & 29.94 & 274.36 & 220.87 \\
\hline & $\mathrm{Hf}^{3+}$ & 55.11 & 37.20 & 29.03 & 25.40 & 282.34 & 210.06 \\
\hline & $\mathrm{Zr}^{4+}$ & 56.08 & 37.54 & 26.31 & 29.94 & 276.47 & 226.44 \\
\hline
\end{tabular}

